\title{
The Effect of Aerobic Exercises on Students' Physical Fitness
}

\author{
Apri Agus $^{1 *}$, Sepriadi $^{2}$, and Fahd Mukhtarsyah ${ }^{3}$ \\ ${ }^{1,2,3}$ Faculty of Sports Sciences, Universitas Negeri Padang, Padang, Indonesia \\ *Corresponding author. Email: apriagusfik@ gmail.com
}

\begin{abstract}
Physical fitness is one of the problems which have something to do with health issues experienced by many people including university students. Students with a good physical fitness will have good health condition which enables them to do their daily activities without experiencing major fatigue. One method which can be done to improve physical fitness is aerobic exercise. Thus, this quasi-experiment study aimed to figure out the effect of aerobic exercise on students' physical fitness. The sample of this study was 84 students male students selected through purposive sampling method from a population of all students in Sports Science Faculty Universitas Negeri Padang. One Group Pre-test Post-test design was employed in this study. Pre-test was conducted prior to a-24 sessions (8 weeks) of $30-60$ minutes for each aerobic exercise scheduled for three times a week. After this session, students were required to take the post-test. The result of this study showed that aerobic exercise was proven to improve students' physical fitness significantly. This was indicated by the result of data analysis with $t$-test where $t_{\text {calculated }}>$ $\mathrm{t}_{\text {table }}=1.364$ so that it can be concluded that there is a significant impact of a 24 -session aerobic exercise on students' physical fitness.
\end{abstract}

Keywords: Aerobic, Aerobic exercise, physical fitness

\section{INTRODUCTION}

Physical activity is a habit that cannot be separated from every single human being in this world. Humans never stop moving and every human has different activities every time. Even when a person sleeps, his or her heart unwittingly continues to move pumping blood throughout the body. However, as technology develops from all fields, the level of awareness of physical activity which is very important for human health is still very low. So many people do not want to exercise, even though they know that exercise is very beneficial for health.

Nowadays, the role of sports is increasingly important both for improving health, fostering the younger generation and for achieving in the field of sports which ultimately can elevate the nation's dignity. To realize this, of course, it takes the availability of young people who are qualified and have a good level of physical fitness so that they can continue the baton for the sake of the nation. Good physical fitness will be obtained if supported by nutritious food. These nutrients include: carbohydrates, proteins, fats, vitamins and minerals. These nutrients are essentials for activities and growth, especially for students who are in the first and second year and are still classified as teenagers (18 to 20 years old).
Exercise or physical activity will affect one's physical fitness. Physical fitness becomes highly important as an indicator in supporting the degree of health. This is in accordance with the findings by Sepriadi and Eldawaty who stated that "Physical fitness is one indicator in the development of superior human resources [1]. World Health Organization (WHO) stated that "physical fitness can be achieved if the people have a good degree of health" [2]. One of the physical activities that can affect fitness is aerobic exercise. In addition, physical activity supported by a healthy lifestyle will also improve the degree of health in the community.

Physical activity will directly affect the respiratory cardiovascular system. One of the effects is to increase the pulse and respiratory rate. Aerobic exercise can increase the frequency of pulse, lactic acid in blood, body temperature, and exercise blood pressure. In addition, exercise can also increase the size of the heart, especially the left ventricle, increase blood supply, reduce the frequency of resting pulses, normalize blood pressure, and improve blood distribution [3]. In addition, regular physical exercise has several advantages to the cardiovascular system, including normalizing blood pressure, strengthening the heart muscle, decreasing the frequency of resting pulses, 
and increasing the ability of the cardiovascular system to transport oxygen. Aerobic exercises such as jogging will make the heart beat faster and stronger. This is due to the increasing footsteps in running which make the heart rate increases, and vice versa.

Aerobic exercise with proper intensity which is conducted regularly and continuously will improve the functions of organs in human body, like decreasing the pulse rate of heart. This happens because of the adaptation of the heart's work so that the pulse rate compared to after exercise will decrease. With aerobic exercise, the need for blood that contains oxygen will also be even greater. This need will be fulfilled by the heart by increasing blood flow. This will also be responded by blood vessels by widening the diameter of the blood vessels so that it will have an impact on individual blood pressure. When this process takes place, the blood condition will further thicken and inhibit blood circulation in transporting nutrients and oxygen throughout the body. And this is where the role of bodily fluids is as a counterweight or blood thinner so that the blood is in a normal state and can circulate nutrients and oxygen throughout the body [4]. In addition, aerobic exercise will be able to improve physical fitness where by increasing adaptation of body organs there will also be an increase in physical fitness.

\section{METHODS}

This quasi-experiment research which was to see the effect of aerobic exercise on physical fitness uses the One Group Pre-test Post-test Design. Population in this study was all the students in the Faculty of Sport Science, Padang State University. Through purposive sampling technique, 84 male students were selected to participate in this study.

Before the study began, the sample was given an explanation of the aims, intentions, and procedures of the study. After that, anamnesis was conducted around the examination of medical history, physical examination and the availability of samples to be investigated during the study. After the examination is carried out, then a pre-test was performed on all research subjects using the Cooper Test instrument, a 2400 meter running test [5].

After completing the initial test (pre-test), the research subjects did aerobic exercise with a frequency of 3-times-a-week exercise with 30-60 minutes duration for each exercise for 24 meetings or 8 weeks. After 24 meetings the final test (post-test) is carried out with the same procedure as the initial test (pre-test) to get data on changes given by the treatment. More details about the research treatment design can be seen in the table below.
Table 1. Treatment in this research

\begin{tabular}{|c|c|}
\hline Treatments & Aerobic Exercise Program \\
\hline Frequency & 3 times a week \\
\hline Total frequency & 24 meetings \\
\hline Duration for each exercise & $30-60$ minutes \\
\hline Intensity & $60-85 \%$ Maximum Pulse \\
\hline The length of program & 2 months (8 weeks) \\
\hline
\end{tabular}

Data obtained from measurement were then tested with Lilliefors test to ensure all the requirements are fulfilled. After the data analysis requirements are met followed, we conducted a comparison test (t-test) at a significance level of $5 \%$. The comparative test ( $t$ test) is useful to test the ability of generalization or the significance of research results [6], which is calculated based on the formula of:

$$
t h=\frac{\left|\bar{x}_{1}-\bar{x}_{2}\right|}{\sqrt{\frac{\sum D^{2}-\frac{\left(\sum D\right)^{2}}{n}}{n(n-1)}}}
$$

Information:

$\mathrm{x}_{\overline{1}}=$ Mean pre-test

$\mathrm{x}_{2}=$ Mean post-test

$\mathrm{D}=$ The difference between the $1^{\text {st }}$ and $2^{\text {nd }}$ sample scores

$\mathrm{D}^{2}=$ Different squares

$\sum \mathrm{D}^{2}=$ Number of squares is different

$\mathrm{n}=$ Number of samples

\section{RESULT AND DISCUSSION}

\section{A. Result}

Based on the research conducted on research subjects, we describe the physical fitness of the respondents before and after the treatment was given during the 24 meetings as follows.

1. Pre-Test (Initial Data)

From the preliminary data of physical fitness measurements of students before being given treatment, we found that the mean (average) was 12.36 and belongs to the medium category, the Standard Deviation (SD) of 1.51 , the highest value was 10.10 and belongs to the excellent category, and the lowest value of 17.24 which belongs to the category of very poor. Frequency distribution of physical fitness of students before being given treatment can be seen in the table below. 
Table 1. Initial Data of Physical Fitness

\begin{tabular}{|c|c|c|c|c|c|}
\hline \multicolumn{3}{|c|}{ Class Interval } & $\mathrm{Fa}$ & $\mathrm{Fr}$ & Category \\
\hline \multicolumn{3}{|c|}{$\leq 9: 44$} & 0 & 0,00 & Trained \\
\hline $9: 45$ & - & $10: 45$ & Excellent & 7,14 & Excellent \\
\hline $10: 46$ & - & 12:00 & Good & 33,33 & Good \\
\hline 12:01 & - & 14:00 & Average & 42,86 & Average \\
\hline 14:01 & - & 16:00 & Poor & 13,10 & Poor \\
\hline \multicolumn{3}{|c|}{$\geq 16: 01$} & 3 & 3,57 & Very poor \\
\hline \multicolumn{3}{|c|}{ Sum } & 84 & & \\
\hline
\end{tabular}

In Table 1, we can see that 6 people $(7.14 \%)$ are in the excellent category, 28 people $(33.33 \%)$ are in the good category, 36 people $(42.86 \%)$ are in the moderate category, 11 people $(13.10 \%)$ are in the poor category, and 3 people $(3.57 \%)$ are in the very poor category. For more details, can also be seen in Figure 1 below.

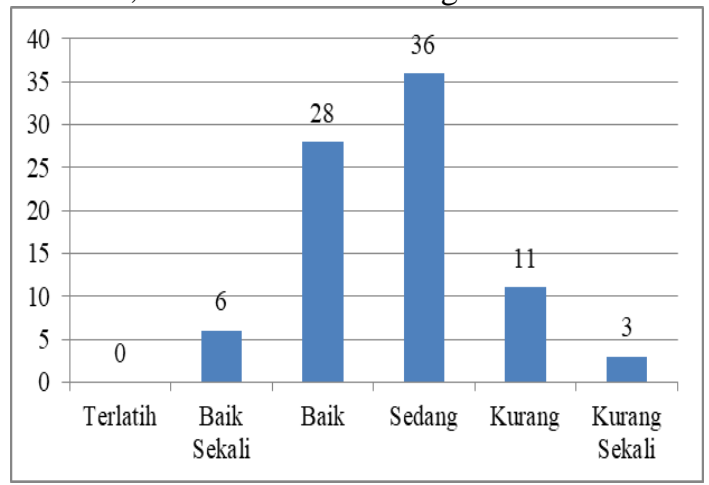

Fig. 1.Initial data of Students' Physical Fitness

\section{2. $\quad$ Post Test (Final Data)}

Based on the final physical fitness data of students after treatment, we obtained the mean (average) was 11.98 (good category), Standard Deviation of 1.47, the highest value of 9.52 (excellent category), and the lowest value of 16.35 (very poor). The frequency distribution of physical fitness of students after being treated is shown in Table 2.

Table 2. Final Data of Physical Fitness

\begin{tabular}{|c|c|c|c|c|c|}
\hline \multicolumn{3}{|c|}{ Class Interval } & $\mathrm{Fa}$ & $\mathrm{Fr}$ & Category \\
\hline \multicolumn{3}{|c|}{$\leq 9: 44$} & 0 & 0,00 & Trained \\
\hline $9: 45$ & 11 & 13,10 & 11 & 13,10 & Very Good \\
\hline $10: 46$ & 29 & 34,52 & 29 & 34,52 & Good \\
\hline $12: 01$ & 35 & 41,67 & 35 & 41,67 & Average \\
\hline 14:01 & 7 & 8,33 & 7 & 8,33 & Poor \\
\hline \multicolumn{3}{|c|}{$\geq 16: 01$} & 2 & 2,38 & Very poor \\
\hline \multicolumn{3}{|c|}{ Sum } & 84 & & \\
\hline
\end{tabular}

Table 2 indicated that after the treatment we found 11 people $(13.10 \%)$ are in the excellent category, 29 people $(34.52 \%)$ are in the good category, 35 people
$(41.67 \%)$ are in the moderate category, 7 people $(8.33 \%)$ are in the poor category, and 2 people $(2.38 \%)$ are in the very poor category. More details can also be seen in Figure 2.

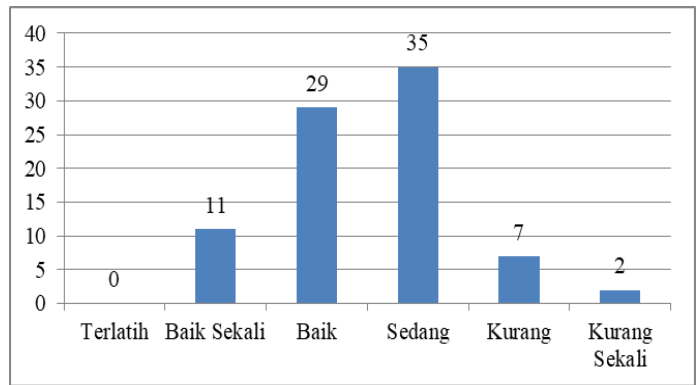

Fig. 2. Final Data of Students' Physical Fitness

\section{B. Hypothesis Testing}

We conducted hypothesis testing using the test of mean differences of dependent samples. The result obtained is as follow.

Table 3. Summary of Hypothesis Testing Results

\begin{tabular}{|l|l|l|l|l|l|}
\hline Data & Mean & $\begin{array}{c}\text { Amount } \\
\text { of } \\
\text { Sample } \\
(\mathrm{N})\end{array}$ & $\mathrm{t}_{\text {calculated }}$ & $\mathrm{t}_{\text {table }}$ & Remark \\
\cline { 1 - 5 } Pre-Test & 12,36 & 84 & 10,665 & 1,364 & Significant \\
\cline { 1 - 5 } Post-Test & 11,98 & 84 & \\
\hline
\end{tabular}

Table 3 showed that our finding is in accordance with the theories that proposed that aerobic exercise provides a significant influence on physical fitness.

\section{Discussion}

The results showed that aerobic exercise for 24 meetings with 84 samples was shown to significantly improve physical fitness. Pre-test data, the average value of physical fitness of the sample group before being treated with a-2400 meter running test time obtained was 12.36 and the time increased to 11.98 after treatment was given. Based on the results of the statistical test analysis through the mean difference test $(\mathrm{t}$-test $)$, the value of $\mathrm{t}_{\text {calculated }}=10.665>\mathrm{t}_{\text {table }}=1.364$. Therefore, it can be concluded that there is a significant effect of a-24-meetings aerobic exercise program on physical fitness.

Physical fitness is a very important factor in supporting daily activities. This is because having good physical fitness will also support a good degree of health too. One of the activities that can be done to improve physical fitness is aerobic practice. Aerobic exercise is often known as "cardio" exercise which requires oxygenated blood pumping by the heart to send oxygen to the working muscles [7]. Furthermore, 
aerobic exercise can also be one way to improve bodily functions and health status [8]. So, we figured out that aerobic exercise not only can improve physical fitness but also can improve health status. This is because with aerobic exercise, the function of body organs, especially the heart will be better so that it can improve the degree of individual health. Aerobic exercise that is done regularly and continuously also with the right intensity will make improvements to the function of the body's organs, especially the heart such as a decrease in pulse rate. This is caused by aerobic exercise so that the efficiency of the heart works so that the heart will beat less than the untrained heart [9].

Aerobic exercises that are carried out continuously and regularly can increase the degree of fitness are aerobic exercises. The exercise must be done 3 times a week within 24 meetings for 8 weeks [10]. The exercise can be done for 30-60 minutes each time with the intensity of the exercise is $60-85 \%$ of the maximum pulse rate.

Aerobic exercise affects the function of the cardiorespiratory system. Especially those that are related to the transport of oxygen in the body, which will eventually means that physical fitness will also increase. In addition, aerobic exercise also involves various integrated systems that seek to facilitate the transport of oxygen to active parts of the body and reduce the delivery of oxygen to inactive or less active parts of the body [11]. Aerobic exercise helps oxygen delivery to the muscles that are more active and faster and more if compared with no exercise. So with that, the aerobic exercise that is organized will also be able to improve physical fitness so that when doing daily activities we will not get tired easily.

A fit body is a body that is able to do activities without experiencing significant fatigue. This can occur because of the efficiency of the performance of the organs of the body, especially the heart and lungs. With regular exercise, the heart's work will be more efficient where blood will flow better to the muscles during exercise. Therefore, the workload of the heart will be reduced. Heart rate response during exercise causes the pulse frequency to decrease. This will result in the decrease in frequency of resting pulses. The resting pulse rate of someone who often does aerobic exercise will be lower than the untrained one. This is due to an increase in parasympathetic stimuli and a decrease in sympathetic stimuli [11]. If the resting pulse is lower then this means the better because physiologically the work of the heart becomes more effective and efficient. So, by doing regular aerobic exercise can reduce the frequency of resting pulse rates.

At rest, a fit body will make oxygen consumption to be more efficient because regular aerobic exercise help our body to be more efficient in consuming oxygen. The efficiency of performance occurs due to an increase in the working conditions and efficiency of respiratory muscles, enabling the use of greater capacity. So, with aerobic exercise done regularly and the right intensity, it will be able to improve physical fitness. With good physical fitness, it will also improve the degree of health. So as to be able to achieve a degree of health and fitness can be done with regular aerobic exercise and proper intensity.

\section{CONCLUSION}

Based on data analysis and discussion that has been presented previously, it can be concluded that aerobic exercise that is carried out regularly can improve student physical fitness. We recommend a program of aerobic exercise with 24 meetings with 3-times-a-week exercise for 8 weeks, and the training load of $60-85 \%$ of the maximum pulse.

\section{REFERENCES}

[1] S, Sepriadi and E, Eldawaty.. The Contribution of Hemoglobin Levels to Students' Physical Fitness ACTIVE: Journal of Physical Education, Sport, Health and Recreation, 2019.

[2] World Health Organization (WHO). Global strategy on Diet, Physical activity and Health. 2003. [Online] Available at: http://www.who.int/dietphysicalactivity/media/en/g sfs.

[3] Sharkey, B. J. Kebugaran dan Kesehatan. Cetakan ke dua. Jakarta: PT. Raja Grafindo Persada Devisi Buku Sport. 2011.

[4] Hermawan, L., Subiyono, H. S., \& Rahayu, S. Pengaruh Pemberian Asupan Cairan (Air) terhadap Profil Denyut Jantung pada Aktivitas Aerobik. Journal of Sport Sciences and Fitness, 1(2), 2012.

[5] Agus, A. and Sepriadi. Manajemen Kebugaran. Padang: Sukabina Press, 2018.

[6] Arikunto, Suharsimi. Prosedur Penelitian Suatu Pendekatan Praktik. Jakarta: Rineka Cipta, 2016.

[7] Weil, R., and Stöppler, M. C. Aerobic Exercise, 2015

[8] Aguiar, L. T., Nadeau, S., Britto, R. R., TeixeiraSalmela, L. F., Martins, J. C., and de Morais Faria, C. D. C. Effects of aerobic training on physical activity in people with stroke: protocol for a randomized controlled trial. Trials, 19(1), p: 446 2018.

[9] Almeida, M. B., and Araújo, C. G. S. Effects of aerobic training on heart rate. Revista Brasileira de Medicina do Esporte, 9(2), pp. 113-120, 2003.

[10] Karacan, S. Effects of long-term aerobic exercise on physical fitness and postmenopausal symptoms 
with menopausal rating scale. Science \& Sports, 25(1), pp. 39-46, 2010.
[11]Fox EL, Bower RW, Foss ML. The Physiological Basic of Physical Education and Athletics. $4^{\text {th }}$ ed. Philadelphia: Sauders College Publishing, 1988. 